Ilona Skupińska-Lovset

\title{
Sympozjum naukowe poświęcone najnowszym badaniom wybranych aspektów kultury starożytnej Palestyny (tódź 2005)
}

W semestrze wiosennym 2005 roku Pracownia Archeologii Śródziemnomorskiej Uniwersytetu Łódzkiego skoncentrowała swoją działalność statutową na naświetleniu problematyki związanej z badaniami nad kulturą starożytnej Palestyny. Impulsem było planowane ukazanie się publikacji profesor Ilony Skupinskiej-Lovset zatytułowanej The Temple Area of Bethsaida. Polish Excavations on et-Tell in the Years 1998-2000. Publikacja ta podsumowuje trzyletnie badania terenowe na et-Tell identyfikowanym z biblijną Betsaidą. Jest rzeczą znaną, że w wyniku dotychczasowych badań archeologicznych prowadzonych przez międzynarodowe konsorcjum od roku 1989 wielowiekowy spór naukowy o położenie Betsaidy został rozstrzygnięty właśnie na korzyść stanowiska et-Tell, a odsłonięta w wyniku wykopalisk osada wczesnorzymska ogłoszona została w roku 2000 miejscem świętym.

Wiele pytań związanych z tym właśnie poziomem osadniczym czeka na naukowe wyjaśnienie. Wśród nich naczelne miejsce zajmuje szczegółowy opis interpretacyjny miejsca kultu Betsaidy identyfikowanego dotąd zmiennie jako synagoga czy też świątynia kultu cesarskiego. W tym właśnie punk- 
cie prowadziła badania Międzyuczelniana Polska Misja Archeologiczna, nic więc dziwnego, że omówienia polskich badań przedstawiane przez autorkę na kolejnych międzynarodowych kongresach organizowanych przez Society of Biblical Literature w Berlinie w 2002 roku i w Gronningen w 2004 roku spotkały się z ogromnym zainteresowaniem. Zauważyć bowiem należy związki rozplanowania miejsca kultu na et-Tell z kulturą fenicką, a szczególnie ze świątyniami takimi, jak świątynia Apollina w Tyrze.

Pogłębieniem tegorocznych rozważań na tle porównawczym były dyskusje związane z pobytem naukowym profesora Uniwersytetu Jana Gutenberga w Moguncji Wolfganga Zwickela na Uniwersytecie Łódzkim (6-10 kwietnia 2005). Prof. Wolfgang Zwickel, kierownik Lehrstuhl für Altes Testament und Biblische Archäologie, jest czołowym biblistą; po odejściu prof. Volkmara Fritza przejął on kierowane przez niego wykopaliska w Galilei.

Niektóre zagadnienia związane z wykopaliskami na tel Kinrot były nam już znane. Kilka lat temu grupa studentów archeologii Uniwersytetu Łódzkiego w ramach stypendium DAAD miała możliwość uczestniczenia w specjalnym seminarium zorganizowanym właśnie przez prof. Fritza celem zapoznania się z problematyką badań na wzgórzu tel Kinrot. Wszyscy pamiętamy zaangażowanie profesora w problematykę archeologiczną, jego entuzjazm i gościnność, a szczególnie wspólne seminarium w lokalach Justus-Liebig-Universität w Gießen. Niestety choroba uniemożliwiła profesorowi Fritzowi dalszą pracę naukową. Tel Kinrot, o którym mówił teraz profesor Zwickel, jest najbliższym sąsiadem Betsaidy, oddalonym zaledwie o ok. 4 km. Wzgórze leży w Galilei i nadmienić należy, że w toku „sporu o Betsaidę" istniały też propozycje identyfikacji osady na wzgórzu tel Kinrot z biblijną Betsaidą. Tel Kinrot, w języku arabskim Tell el-Oreme, leży jak Betsaida w rowie tektonicznym, wznosząc się do wysokości $125 \mathrm{~m}$ poniżej poziomu morza. Wykopaliska zarejestrowały tu osadnictwo od okresu chalkolitycznego po okres Otomanów. Jednak okres świetności osadnictwa przypada na XI-X w. p.n.e. Tenże okres jest bogato reprezentowany na et-Tell, a świetność poprzedniczki Betsaidy, jak udowadniają wykopaliska, znacznie przekraczała świetność miasta z pierwszego okresu żelaza na tel Kinrot. Odkryto tu bowiem wspaniałe mury miejskie, największą znaną bramę miejską posiadającą dwa pomieszczenia w każdej baszcie, miejsce kultu przy bramie oraz założenie pałacowe typu bit hilani.

Wykopaliska na tel Kinrot odsłoniły obwarowane miasto dostarczając bogatego materiału archeologicznego, ilustrującego jego historię do podboju asyryjskiego. Po podboju asyryjskim osadnictwo na terenie przyległym do północnej części jeziora Galilejskiego podupada. Zaczyna się dopiero nasilać w całym regionie od około roku 300 p.n.e. Jednak w odróżnieniu 


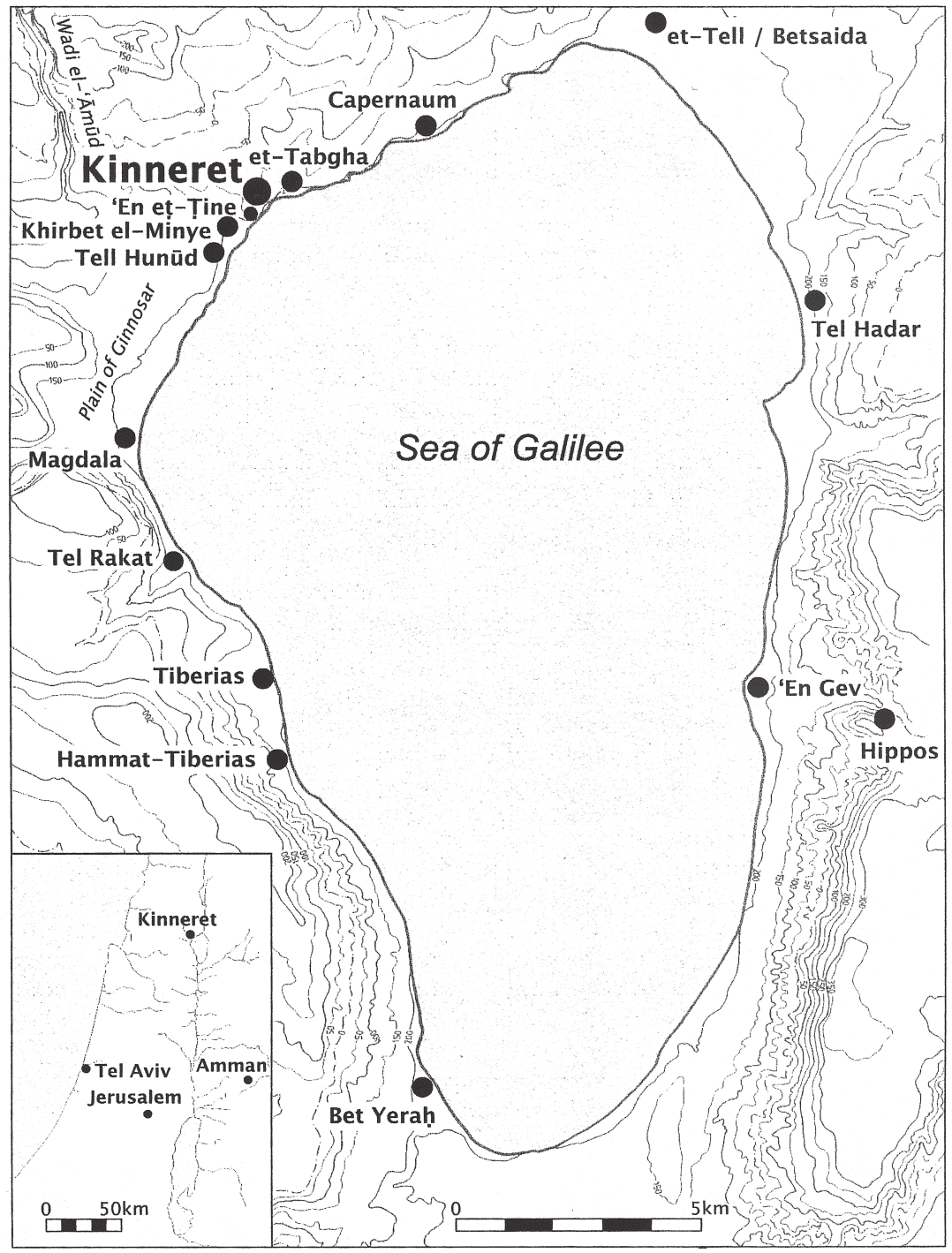

Osadnictwo nad Jeziorem Galilejskim (rys. R. Kratz, S. Münger) 
od Betsaidy okres hellenistyczny i rzymski jest słabo reprezentowany na tel Kinrot. Działalność osadnicza wydaje się być raczej ukierunkowana na wschód i południe od telu. W zachodniej strefie przybrzeżnej powstają takie miasta, jak Magdala, Kafarnaum i Ammathous (Hammat Tiberias) założone po podboju Galilei przez Hasmoneuszów około roku 104 p.n.e., a w okresie rzymskim założona zostaje Tyberiada, stolica regionu.

Ważną część sympozjum stanowiła kwestia prezentacji najnowszych badań dotyczących świątyni Salomona w Jerozolimie, bez której niemożliwe są studia zabytków sakralnych także epoki hellenistycznej i rzymskiej. Zagadnieniu temu poświęcił profesor Zwickel publikację książkową Der salomonische Tempel von seiner Gründung bis zur Zerstörung durch die Babylonier, Mainz 1999 (Kulturgeschichte der Antiken Welt, 83). Problemowi kultu na terenie starożytnej Palestyny poświęcił on poza tym większość swoich rozpraw, w tym doktorską i habilitacyjną. Wykład był bogato ilustrowany i prezentował bardzo obszerny materiał porównawczy. Dyskusja, która wywiązała się po wykładzie, koncentrowała się na ustaleniu wysokości i konstrukcji elementów zadaszenia świątyni Salomona, problemie wysokości bemy, wyposażenia jak tron, metalowe przedmioty kultowe i inny wystrój.

Ostatnie zagadnienie, które poddane zostało dyskusji, miało charakter ikonograficzny. Chodziło tu o występowanie wizerunku orła w sztuce judaizmu. Symboliczną interpretację tego zjawiska streścił dr Paweł Szkołut. Obronił on wiosną tego roku swoją monumentalną, bo 524-stronicową pracę doktorską zatyłowaną Symbol orła w sztuce judaizmu okresu rzymskiego $i$ wczesnobizantyjskiego. W ambitnym założeniu miała być ona pierwszym w perspektywie światowej całościowym omówieniem tego zagadnienia. Skrócona wersja pracy ukaże się drukiem w serii Monografie Instytutu Archeologii Uniwersytetu Łódzkiego. 